\title{
Treatability of landfill leachate by combined upflow anaerobic sludge blanket reactor and aerated lagoon
}

\author{
S. Govahi · A. Karimi-Jashni • M. Derakhshan
}

Received: 12 November 2010/Revised: 25 April 2011/Accepted: 21 August 2011/Published online: 11 December 2011 (c) CEERS, IAU 2011

\begin{abstract}
Continuous upflow anaerobic sludge blanket reactor performs more favorably at the higher organic loading rate than other anaerobic treatment. The treatment of municipal landfill leachate of Shiraz's city investigated using continuous flow anaerobic reactor and subsequently aerated lagoon. Landfill leachate has chemical oxygen demand of 45,000-90,000 $\mathrm{mg} / \mathrm{L}$ and ammonia nitrogen at $1,000-2,500$ and heavy metals that can impact biological treatments. Capacity of anaerobic and aerobic reactors is 10 and $20 \mathrm{~L}$ that operated at detention time of 2 and 4 days, respectively. Organic loading rate of upflow anaerobic sludge blanket is between $0.5-20 \mathrm{~g}$ chemical oxygen demand/L/day. Chemical oxygen demand removal efficiencies are between 57-87, 35-70 and 66-94\% in the anaerobic, aerobic and whole system, respectively. As the entry, leachate organic loading rate increased from 1 to $20 \mathrm{~g} / \mathrm{L} /$ day, the chemical oxygen demand removal efficiency reached a maximum of $71 \%$ and $84 \%$ in the anaerobic reactor and whole system, respectively, at high organic loading rate. Ammonium removal efficiency was about $54 \%$ after the aerobic stage.
\end{abstract}

S. Govahi $(\bowtie)$

Department of Civil Engineering, Behbahan Branch, Islamic Azad University, Behbahan, Iran

e-mail: saeid_govahi@yahoo.com

\section{A. Karimi-Jashni}

Department of Civil and Environmental Engineering,

Faculty of Engineering, Shiraz University, Shiraz, Iran

M. Derakhshan

Department of Civil, Behbahan Branch,

Islamic Azad University, Behbahan, Iran
Keywords Biogas - Efficiency $\cdot$ Removal $\cdot$ Sequential · Treatment

\section{Introduction}

Commercial and industrial development in many countries around the world during past decades have increased generations of urban and industrial solid waste rapidly (Lin et al. 2000). Most of the soild waste from communities is disposed in sanitary landfills, where it receives (undergoes) physical, chemical and biological alterations. Dissolved organic and inorganic substances in water create a leachate, where its treatment can be troublesome (Wu et al. 2003). The removal of COD, BOD and ammonium of leachate is the common prior condition before discharging the leachate into natural waters (Agdag and Sponza 2004). High COD and high COD/BOD ratio of the landfill leachate is the cause for the anaerobic treatment which is more advantageous when compared to aerobic treatment process (Fikret and Pamukoglu 2003). Anaerobic treatment methods are more suitable for the treatment of concentrated leachate streams, which offers lower operating costs and the production of usable biogas product and production of a pathogen-free solids residue which can be used as cover material (Park et al. 2001).

Anaerobic wastewater treatment is a recognized, wellestablished and proven technology for the treatment of various types of industrial wastewaters (Cakir and Stenstrom 2005). High-rate anaerobic processes such as up-flow anaerobic sludge blanket reactor (UASB) and anaerobic filter have been shown to be efficient in the treatment of leachate having a COD higher than $800 \mathrm{mg} / \mathrm{L}$ and the $\mathrm{BOD} / \mathrm{COD}$ ratio higher than 0.3. Hoilijoki investigated nitrification of anaerobically pre-treated municipal landfill 
leachate in lab-scale activated sludge reactor (Sahrigi et al. 2002). Aerobic post-treatment produced effluent with COD 150-500 $\mathrm{mg} / \mathrm{L}$, BOD less than $7 \mathrm{mg} / \mathrm{L}$ and on an average, NH4-N less than $13 \mathrm{mg} / \mathrm{L}$.

Agdag et al. studied treatment of the leachate is produced from the organic fraction of municipal solid waste (food) in a sequential two-staged up-flow anaerobic sludge blanket (UASB)/aerobic continuous stirred tank reactor (CSTR) at a different organic load rate (Agdag and Sponza 2004). COD removal efficiencies of the first and the second anaerobic and aerobic total system were 79, 42, 89 and 98\%, respectively, at a COD loading rate of 4.3, 5.76, 7.2, 10.4, 12.8 and $16 \mathrm{~g} / \mathrm{L}$ per day. The methane content of the first UASB was approximately $60 \%$. The NH4-N removal efficiency of the total system was $99.6 \%$ after the aerobic stage. Complete removal of COD and $\mathrm{NH}(3)-\mathrm{N}$ was reported for combined reverse osmosis (RO) and UASB with an initial COD concentration of $35,000 \mathrm{mg} / \mathrm{L}$ and $\mathrm{NH}(3)-\mathrm{N}$ concentration of $1,600 \mathrm{mg} / \mathrm{L}$ (Kurniawan et al. 2010).

Anaerobic biological treatment of landfill leachate has been studied by many investigators. Up to $92 \%$ chemical oxygen demand (COD) removals have been obtained using upflow anaerobic sludge blanket reactors (Kennedy and Lentz 2000). Anaerobic and sequential anaerobic-aerobic reactors have been used for landfill leachate treatment at different temperatures such as 11 and $24^{\circ} \mathrm{C}$ (Marttinen et al. 2002). Nearly $75 \%$ COD removals have been achieved by anaerobic treatment at $24^{\circ} \mathrm{C}$ with a $10-\mathrm{h}$ hydraulic retention time (HRT). The overall COD removal in the sequential process was $80-90 \%$ with nearly $80 \%$ ammonium removal. Maehlum (1995) used on-site anaerobic-aerobic lagoons and formed wetlands for biological treatment of landfill leachate. Overall N, P and Fe removals obtained in this system were above $70 \%$ for diluted leachate. A combination of anaerobic-aerobic and rotating biological contact (RBC) processes has been used for leachate treatment by Park et al. (2001). The effluent of the RBC process was subjected to flocculation-sedimentation; adsorption and finally reverse osmosis and nearly $98 \%$ of the organic materials of low MW have been removed. The average for ferric chloride and neutraolor have been removed in color (97 and 84\%), COD (47 and 44\%), biochemical oxygen demand (BOD) (75 and 96\%), detergents (56 and 85\%), arsenic (86 and 86\%) and cyanide (97 and $74 \%$ ) with physico-chemical treatment (Madera and Viviana 2009).

Location of this study was the landfill of Shiraz at Iran and the year was 2008. Some problem Shiraz's Landfill is that, it is not applied by a leachate collection system and produces leachate with high organic matter above $50,000 \mathrm{mg}$ COD/L. The objective of this research has been done to determine treatability of landfill leachate of Shiraz city from Iran in upflow anaerobic sludge blanket (UASB)/ aerated lagoon $\mathrm{COD}, \mathrm{BOD}_{5}$ removal, alkalinity, $\mathrm{NH}_{4}-\mathrm{N}$ variation in anaerobic/aerobic reactors were evaluated.

Experimental laboratory-scale reactors and seed

One continuously fed PVC anaerobic UASB and an aerobic CSTR reactor were used in sequence for the experimentation. The UASB reactor had $10 \mathrm{~L}$ of effective volume with an internal diameter of $7.4 \mathrm{~cm}$ and a height of $160 \mathrm{~cm}$. Nine sampling ports (20 and $30 \mathrm{~cm}$ apart at bottom and top, respectively) were provided to quantify the sludge characteristics at different elevations along the reactor. It was operated at $25-40^{\circ} \mathrm{C}$ using a warm water tube located around the reactor. The CSTR reactor consisted of an aeration tank by effective volume of $20 \mathrm{~L}$. First to forth port regulates 20,30, 40 and $60 \mathrm{~L}$ of lagoon volume for fixing of organic loading rate. A schematic of the laboratory-scale sequential UASB and CSTR reactors used in this study is presented in Fig. 1. Dissolved oxygen concentration was kept higher than $2 \mathrm{mg} / \mathrm{L}$ in the CSTR reactor. Anaerobic sludge was used as seed in UASB reactor and was taken from invert of anaerobic ponds of RAMAK industry in Shiraz's city. It has $45 \mathrm{~g}$ VSS/L.

\section{Analytical procedures}

The COD in the influent and effluent samples were determined by the closed reflux colorimetric method. Gas production was measured by a liquid displacement method. Total gas was measured by passing the gas through distilled water containing $2 \% \mathrm{H}_{2} \mathrm{SO}_{4}(\mathrm{w} / \mathrm{v})$ and $10 \% \mathrm{NaCl}$ (w/v) (Gulsen and Turan 1999, 2002). Methane gas was detected using 3\% $\mathrm{NaOH}(\mathrm{w} / \mathrm{v})$ containing distilled water (Boiler and Gujer 1986). Temperature, $\mathrm{pH}$ and dissolved oxygen were measured using a pH meter (WWT pH 330), an electronic digital heater and an oxygen meter (WWT Oxi 330), respectively. Ammonia nitrogen and nitrate were measured using spectroquant kits numbered 14752 and 14542 in a photometer Merck SQ 300. Heavy metal measured by atomic adsorption as describe in standard method. Alkalinity was measured by titration with acid to $\mathrm{pH}=4.5$. Other routine analyses, including alkalinity, nitrogen, and phosphorus were performed using procedures outlined in standard methods.

Wastewater composition

The leachate was brought from Shiraz sanitary landfill once every month. Shiraz Landfill leachate was characterized by high COD and ammonia concentrations. The composition of leachate as feed used is provided in Table 1. 
Fig. 1 Schematic of laboratoryscale of UASB and aerated lagoon used for treatment of Shiraz's landfill leachate

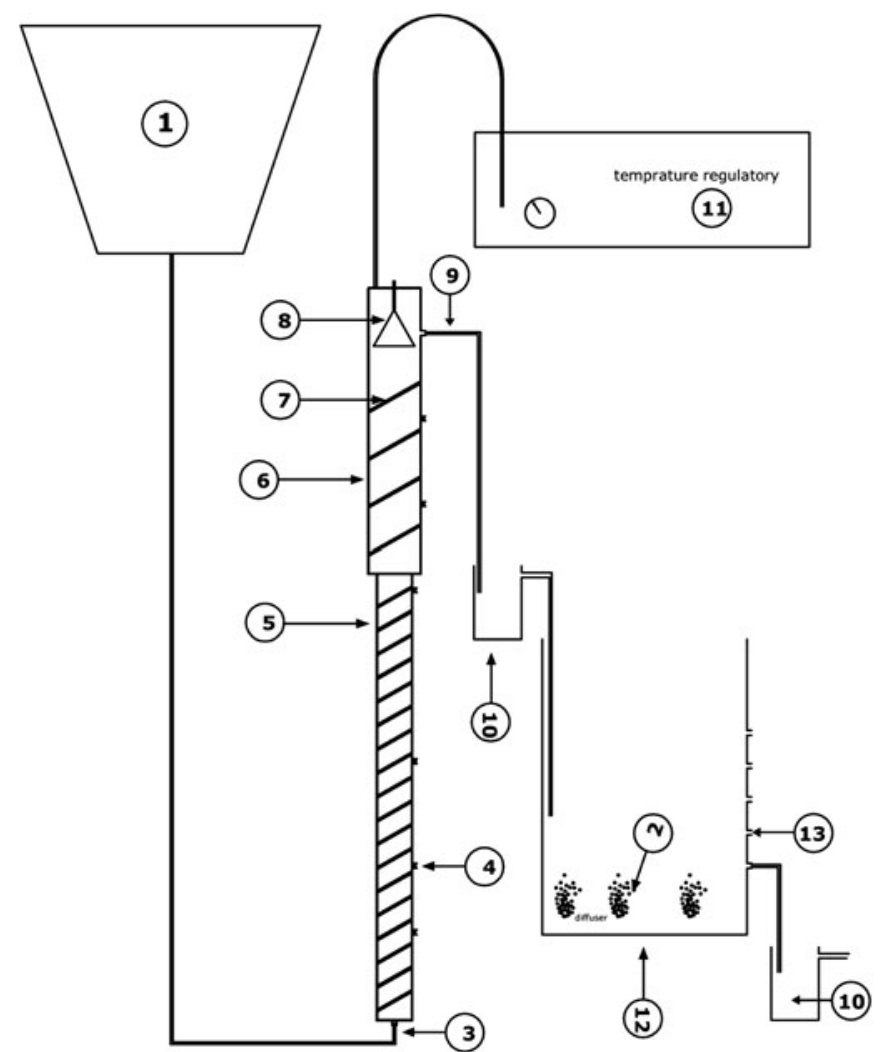

1) leachate storage

2) Diffuser

3) Influent

4) UASB Sampling Port

5) PVC Tube $D=7.4 \mathrm{Cm}$

6) PVC Tube $D=11 \mathrm{~cm}$

7) Warm Water Tube

8) Gas Collector

9) Effluent

10) Settling Chamber 1 lit

11) Temperature Regulator

12) Aerated lagoon

13) HRT control port
Table 1 Composition of leachate as feed used

\begin{tabular}{lllllc}
\hline $\begin{array}{l}\text { Lagoon } \\
\begin{array}{l}\text { HRT } \\
(\text { day })\end{array}\end{array}$ & $\begin{array}{l}\text { UASB } \\
\text { HRT } \\
(\text { day })\end{array}$ & $\begin{array}{l}\text { Feed } \\
\mathrm{NH}_{4}-\mathrm{N} \\
(\mathrm{mg} / \mathrm{L})\end{array}$ & $\begin{array}{l}\text { Feed } \\
\mathrm{COD} \\
(\mathrm{mg} / \mathrm{L})\end{array}$ & $\begin{array}{l}\text { OLR } \\
(\mathrm{g} / \mathrm{L} / \\
\text { day })\end{array}$ & $\begin{array}{l}\text { Operation } \\
\text { period }\end{array}$ \\
\hline 4 & 2 & 115.6 & 1,000 & 0.5 & $0-15$ \\
4 & 2 & 200 & 2,000 & 1 & $15-45$ \\
4 & 2 & 425 & 10,000 & 5 & $45-60$ \\
4 & 2 & 500 & 14,000 & 7 & $60-85$ \\
6 & 2 & 550 & 20,000 & 10 & $85-110$ \\
6 & 2 & 650 & 30,000 & 15 & $110-125$ \\
6 & 2 & 802 & 35,000 & 17.5 & $125-150$ \\
6 & 2 & 810 & 40,000 & 20 & $150-165$ \\
\hline
\end{tabular}

\section{Operating conditions}

This study was carried out 160 days. During the start-up period, the reactors were fed with diluted landfill leachate containing, $\mathrm{NaHCO}_{3}$ having a $\mathrm{COD}$ concentration of $1,000 \mathrm{mg} / \mathrm{L}$ and an organic loading rate of $1 \mathrm{~kg} / \mathrm{m}^{3} /$ day. The start-up phase took about 1 month with no leachate addition. After the start-up period, the COD concentration of leachate was steadily increased from 1,000 to $60,000 \mathrm{mg} / \mathrm{L}$ by an increase in the dilution factor. The sequential reactor was operated at constant flow rate $5 \mathrm{~L} /$ day. Hydraulic retention times were 2 and 4 days in anaerobic and aerobic step, respectively. A constant temperature room was used to maintain the temperature of the reactors at $25 \pm 5^{\circ} \mathrm{C}$ in the summer and warm water tube in winter. To monitor the performances of the reactors, influent and effluent $\mathrm{pH}$ were measured daily, while $\mathrm{COD}$ and $\mathrm{NH}_{3}-\mathrm{N}$ were monitored in steady state condition. The attainment of the steady state was verified by checking whether the mean of the effluent characteristics for the last two measurements was remaining relatively constant. No dilution or recycling of feed was made in the beginning or at any of the phases of the study. TSS was monitored once a week. All analyses were carried out in accordance with the standard methods. Biomass concentration at bottom of reactor measured once a month. To compare the final biomass concentration and distribution in the reactors, sludge samples were taken from all the sampling ports at day 130 and SS, VSS, pH and COD were measured.

The effluent of the anaerobic UASB reactor was used as the influent of the aerobic reactor. The operation conditions of the sequential reactor system are shown in Table 2 and Fig. 2.

\section{Results and discussion}

\section{Characterization of the landfill leachate}

Typical composition of the landfill leachate obtained from the Shiraz Landfill area in Iran is presented in Table 1. 
Table 2 Operation features of the system

\begin{tabular}{llllll}
\hline Feature & Sample 1 & Sample 2 & Sample 3 & Sample 4 & Sample 5 \\
Date & $08 / 10 / 2008$ & $09 / 21 / 2008$ & $09 / 24 / 2008$ & $10 / 27 / 2008$ & $11 / 25 / 2008$ \\
\hline COD (total) & $54,100^{\mathrm{a}}$ & 41,000 & 75,000 & 89,000 & 76,000 \\
$\mathrm{COD}$ (s) & 54,096 & 37,584 & 74,500 & 85,000 & 74,500 \\
$\mathrm{BOD}_{5}$ (t) & 50,000 & 37,000 & 42,500 & 62,300 & 53,000 \\
$\mathrm{BOD}_{5}$ (s) & 50,000 & 34,000 & 42,100 & 61,400 & 51,000 \\
$\mathrm{TSS}$ & 1,500 & 2,000 & 500 & 1,367 & 1,550 \\
$\mathrm{PO}_{4}$ & 30 & 24 & 27 & 38 & 21 \\
$\mathrm{NH}_{3}$ & 1,368 & 1,420 & 2,805 & $2,231.3$ & 1,750 \\
$\mathrm{ALK}$ & 15,000 & 12,000 & 25,000 & 11,000 & 9,000 \\
$\mathrm{Zn}$ & 15 & 8 & 17 & 7.56 & 9 \\
$\mathrm{Mn}$ & 0 & 4 & 0 & 1.64 & 5.34 \\
$\mathrm{Cu}$ & 0 & 0 & 0 & 0.29 & 0.36 \\
$\mathrm{Ni}$ & 0 & 0 & 0 & 0.77 & 1 \\
$\mathrm{pH}$ & 5.5 & 5.7 & 6.5 & 5.8 & 5.6 \\
\hline
\end{tabular}

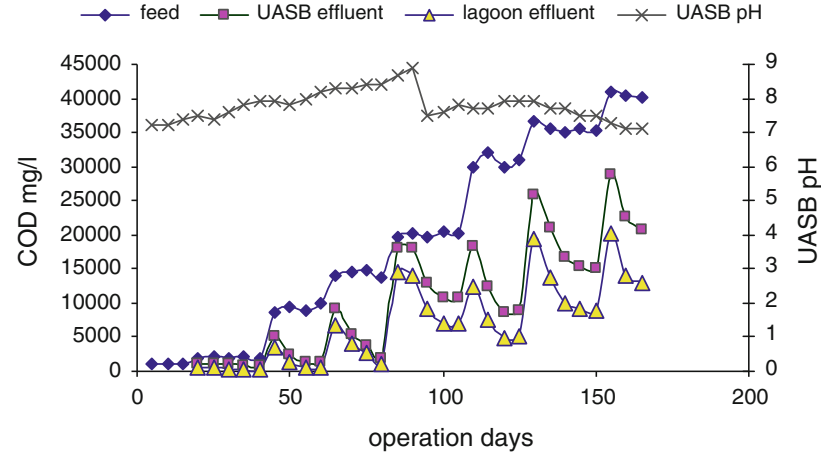

Fig. 2 Operation days for anaerobic and aerobic system

$\mathrm{BOD}_{5} / \mathrm{COD}$ ratio in the leachate was nearly 0.9 at summer and 0.6-0.7 at fall. High and low temperature in summer and fall and variation of food materials and type of consumption and solid waste management cause a decrease of biodegradable organic component of solid waste at fall in Shiraz's city. COD/NH $\mathrm{N}_{4}-\mathrm{N} / \mathrm{PO}_{4}-\mathrm{P}$ ratio in the raw leachate was about 300/7.5/0.3 indicating high $\mathrm{NH}_{4}-\mathrm{N}$ and low $\mathrm{PO}_{4}-$ $\mathrm{P}$ content. Since COD/N/P ratio should be around 300/5/1 for the anaerobic treatment of wastewater, extra $\mathrm{PO}_{4}-\mathrm{P}$ was added to the leachate by $\mathrm{K}_{2} \mathrm{H}_{2} \mathrm{PO}_{4}$ for nutrient balancing in the experimental studies.

COD removal in the sequential UASB and CSTR reactors

COD concentrations in effluent of reactors 1 and 2 increased as the OLRs were increased from 1 to $7 \mathrm{~g} / \mathrm{L} /$ day. In the other words, COD removal efficiencies increased as the OLRs increased. COD and $\mathrm{pH}$ values of feed are shown in Fig. 2. As seen in Figs. 3 and 4, the COD removal efficiency increased to 87 from $59 \%$ as the OLR was increased to 7 from $1 \mathrm{~kg} / \mathrm{m}^{3} /$ day. The COD removal

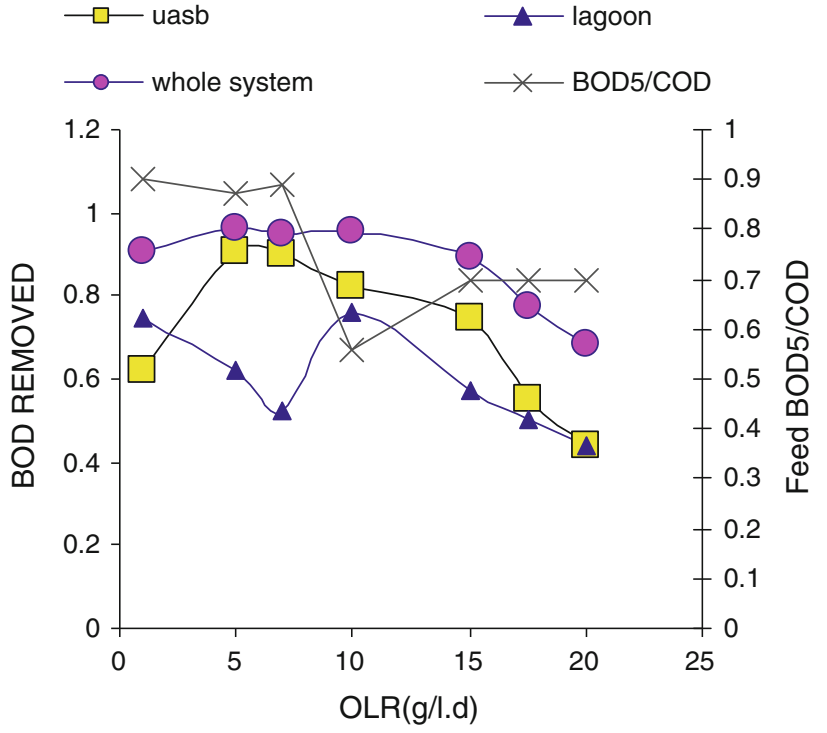

Fig. 3 BOD removal in anaerobic and aerobic steps

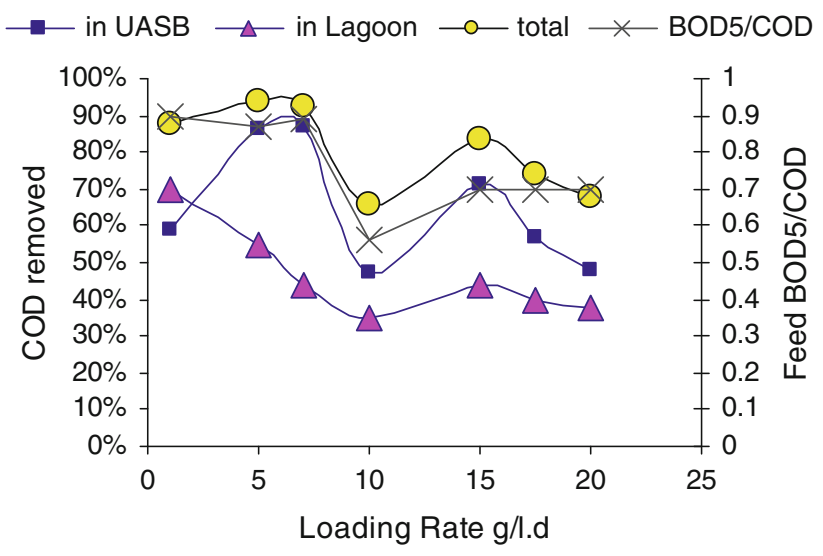

Fig. 4 COD removal in anaerobic and aerobic steps 
efficiencies decreased to about $47 \%$ at OLR of $10 \mathrm{~kg} / \mathrm{m}^{3}$ as temperature decreased. Most anaerobic wastewater treatments have been conducted within mesophilic $\left(30-40^{\circ} \mathrm{C}\right)$ or thermophilic $\left(45-60^{\circ} \mathrm{C}\right)$ temperature ranges (Dhaked et al. 2010; Fang et al. 2006). To achieve COD removal efficiencies above $70 \%$, temperature was adjusted with warm tube. Since the COD removal efficiency increased to 71 from $47 \%$ as the OLR was increased to 15 from $10 \mathrm{~kg} /$ $\mathrm{m}^{3} /$ day. As the COD in the influent was increased from 2,000 to $14,000 \mathrm{mg} / \mathrm{L}$, the COD removal efficiencies increased in the UASB reactor, indicating the anaerobic UASB reactor is resistant to high COD concentrations. As seen in Figs. 3 and 4, the BOD5/COD ratio measured in the leachate samples support biodegradability. The COD removals varied between 35 and $70 \%$ in the effluent of second (CSTR) reactor. The total COD removal efficiencies varied between 66 and 94\% in the whole system. In a study carried out by Kettunen et al. (1996), the COD removal was as high as $85-90 \%$ for the whole sequential anaerobic-aerobic treatment while the COD removal efficiency in the anaerobic stage was only $60 \%$.

$\mathrm{NH}_{4}-\mathrm{N}$ removal in the combined UASB reactor and aerated lagoon system

In this study, the $\mathrm{NH}_{4}-\mathrm{N}$ concentration of the feed increased by decreasing the leachate dilution rates (increasing of COD and OLRs). $\mathrm{NH}_{4}-\mathrm{N}$ concentrations of influent and effluent of UASB reactor and effluent of the aerated lagoon are shown in Fig. 5. The influent $\mathrm{NH}_{4}-\mathrm{N}$ concentrations were recorded as 115.6, 310, 345, 420, 650, 802 and 810 as the OLRs increased to 20 from $1 \mathrm{~g} / \mathrm{L} /$ day. However, the $\mathrm{NH}_{4}-\mathrm{N}$ concentrations were 238, 450, 470, $620,790,1,010$ and 1,012 in the effluent of UASB reactor as OLRs increase. In other words, $\mathrm{N}-\mathrm{NH}_{3}$ release in UASB reactor because most of the nitrogen in the solid waste

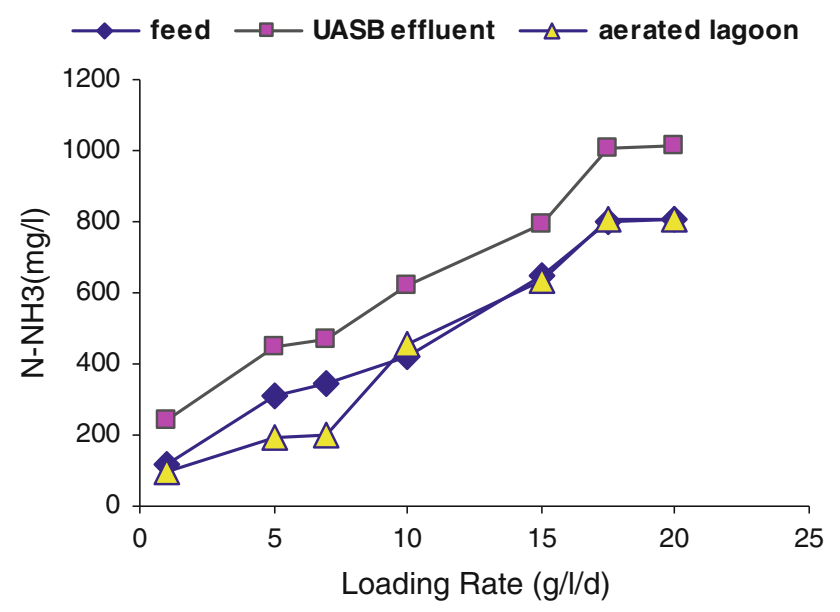

Fig. 5 N-NH3 variation in UASB and aerated lagoon bioreactors is in ammonia form following the degradation of proteins and amino acids (Inanc et al. 2000). Ammonia nitrogen may be incorporated to cell mass. However, only small amounts would be sequestered in this manner as reported by Lin et al. (Gulsen and Turan 2002). Anaerobic ammonium oxidation using $\mathrm{NH}_{4}-\mathrm{N}$ as the electron acceptors could not eliminate the possibility of some $\mathrm{NH}_{4}-\mathrm{N}$ converted to $\mathrm{N}_{2}$ gas (Gulsen and Turan 1999, 2002; Boiler and Gujer 1986; Hollopeter and Dague 1995). In stable anoxic and anaerobic UASB-SBR when the influent ammonia nitrogen $\left(\mathrm{NH}_{4}-\mathrm{N}\right)$ was changed from 155.8 to $1298.0 \mathrm{mg} / \mathrm{L}$, the effluent $\mathrm{NH}_{4}-\mathrm{N}$ was varied from 0.12 to $4.1 \mathrm{mg} / \mathrm{L}$ (Sun et al. 2009). The TN and ammonia nitrogen removal efficiencies of the system consisting of a two-stage UASB, an anoxic and aerobic (A/O) reactor and a sequencing batch reactor (SBR) were 98 and 97\%, respectively (Wu et al. 2009). In this study, $\mathrm{NH}_{4}-\mathrm{N}$ was not removed in anaerobic step. $\mathrm{NH}_{4}-\mathrm{N}$ removal efficiency was about $61,57,57,23,20,20$ and $20 \%$ in the effluent of aerobic reactor as OLRs at feed to combined system increase from 1 to $20 \mathrm{~g} / \mathrm{L} / \mathrm{day}$. This could be explained by nitrification, which occurred in the aerobic reactor at this HRT. In a study carried out by Kettunen et al. (1996). Restraint ammonia nitrogen while feed OLR increases to $7 \mathrm{~g} / \mathrm{L} /$ day was caused that no significant $\mathrm{NH}_{4}-\mathrm{N}$ removal was obtained in the aerobic reactor. Aerobic reactor influent N-NH3 was $620 \mathrm{mg} / \mathrm{L}$ at OLR of 10 larger than $500 \mathrm{mg} / \mathrm{L}$ that has been reported as the nitrification restraint concentration (Gasten and Rozich 1986; Gee et al. 1990). So at OLR of $10 \mathrm{~g} / \mathrm{L} /$ day $\mathrm{NH}_{4}-\mathrm{N}$ removal was decreased strongly in an aerobic system. Its reason may be low detention time so is elevated to 6 from 4 days. At this case N-NH3 removal was not improved in aerobic step. The $\mathrm{NH}_{4}-\mathrm{N}$ concentration decreased from 178 to $35 \mathrm{mg} / \mathrm{L}$ at a HRT of $10 \mathrm{~h}$ in the aerobic stage of the same study. Im et al. (2001), Hies and Mavinic (2001), and Jokela et al. (2002) reported that $\mathrm{NH}_{4}-\mathrm{N}$ removal efficiency was about higher than $90 \%$ in the aerobic stage of the total system.

\section{Gas production in UASB reactors}

During 125 days of operation period, methane productions continuously increased. Figure 6 shows the volumetric methane production rate increases with the OLR addition. As can be seen in this figure, methane gas production increase to $22.5 \mathrm{~L} /$ day as the OLR increased to $15 \mathrm{~g} / \mathrm{L} /$ day in UASB reactor. Up to the loading rates of $15 \mathrm{~g} \mathrm{COD/L/}$ day, methane productions were reduced to about $17.33 \mathrm{~L} /$ day. The highest volumetric methane production rate (2.25 $\mathrm{L} \mathrm{CH}_{4} / \mathrm{L} /$ day) was observed at the volumetric COD loading rate of $15 \mathrm{~g} \mathrm{COD/L/day.} \mathrm{The} \mathrm{carbonaceous} \mathrm{matters}$ in the leachate are converted to methane and carbon dioxide during the anaerobic treatment. Carbon dioxide 


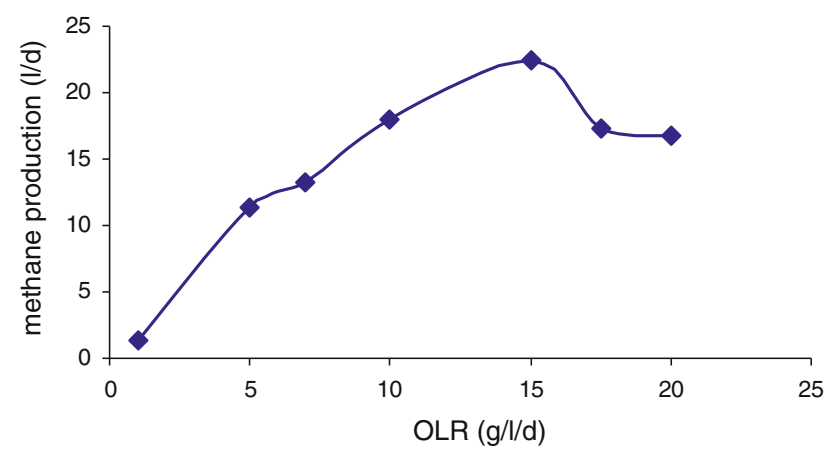

Fig. 6 Effect of OLRs on the methane gas production in UASB system

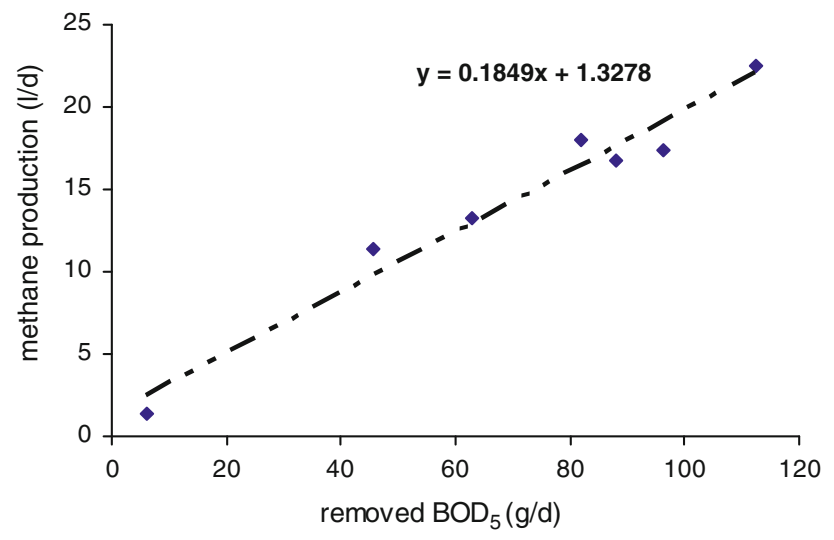

Fig. 7 Correlation of BOD removal and methane production rate for UASB

production does not cause any COD drop. Methane emitted into the gas phase causes BOD drop in leachate. Figure 7 explains that methane production rate increases with the $\mathrm{BOD}$ removal rate. The correlation factor was $0.18 \mathrm{~L}$ gas $/ \mathrm{g}$ BOD $\left(R_{2}=0.96\right)$. In the other words $5.56 \mathrm{~g}$ of $\mathrm{BOD}$ destruction produced $1 \mathrm{~L}$ of methane gas.

\section{Effect of HRT on UASB efficiency}

During this study, HRT was shortened from 5 to 2 days with a subsequent decrease in COD values from 75,000 to $30,000 \mathrm{mg} / \mathrm{L}$ with constant OLR of $15 \mathrm{~g} / \mathrm{L} /$ day. Figure 8 shows the COD removal efficiencies as a role of hydraulic retention time in the anaerobic reactor. The COD removal efficiencies were recorded as 61, 63, 72 and $71 \%$ as the HRTs decrease to 2 from 5 days. As can be seen in this figure the maximum removal efficiency was $72 \%$ at the loading rate of $15 \mathrm{~g} / \mathrm{L} /$ day which was at 3 days HRT. Control of OLRs and upflow velocity is important in efficiency of UASB reactor. In a study reported by Torkian, in upflow velocity of $0.9-1 \mathrm{~m} / \mathrm{h}$ and organic loading rates of 14-25 g COD/L/day, the COD removal efficiency was achieved up to $85 \%$ (Torkian et al. 2004). But because of

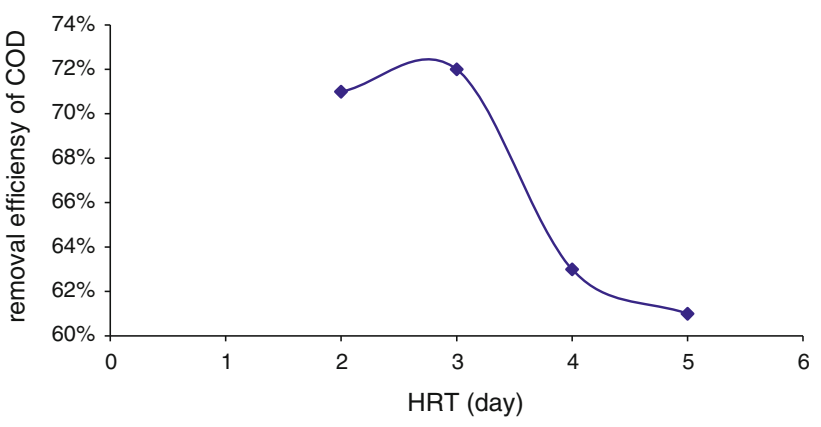

Fig. 8 Removal efficiency of COD with HRT addition

the low upflow velocity $(0.03 \mathrm{~m} / \mathrm{h})$ in this study, the COD removal efficiency was not greater than $72 \%$. Peak HRT has reported by Ramakrishnan is $30 \mathrm{~h}$ at COD of $2,200 \mathrm{mg} / \mathrm{L}$ with phenolic removal efficiency of $94 \%$ (Ramakrishnan and Gupta 2008).

\section{Conclusion}

In this study, the maximum removal efficiency was achieved $71 \%$ at OLR of $5 \mathrm{~g} / \mathrm{L} /$ day for UASB reactor, $75 \%$ for aerated lagoon and $94 \%$ for whole system. $\mathrm{NH}_{4}-\mathrm{N}$ was not removed in anaerobic step but maximum $\mathrm{NH}_{4}-\mathrm{N}$ removal efficiency was about $61 \%$ in the effluent of aerobic reactor when feed COD was $2,000 \mathrm{mg} / \mathrm{L}$. Methane gas production increase to $22.5 \mathrm{~L} /$ day as the OLR increased to $15 \mathrm{~g} / \mathrm{L} /$ day and ideal detention time achieved 3 days in UASB reactor. The result of this study showed that effluent of UASB and CSTR reactors had not been suitable for the environment and alternative treatment such as coagulationflocculation or chemical precipitation is necessary.

\section{References}

Agdag ON, Sponza DT (2004) Anaerobic/aerobic treatment of municipal landfill leachate in sequential two-stage up-flow anaerobic sludge blanket reactor (UASB)/completely stirred tank reactor (CSTR) systems. Environmental Engineering Department, Dokuz Eylul University of Turkey

Boiler M, Gujer W (1986) Nitrification in tertiary trickling filters followed by deep-bed filters. Water Res 20:1363-1373

Cakir FY, Stenstrom MK (2005) A comparison between aerobic and anaerobic wastewater treatment technology. Water Res 39(17): 4197-4203

Dhaked RK, Singh P, Singh L (2010) Biomethanation under psychrophilic conditions. Waste Manage 30(12):2490-2496

Fang HHP, Liang DW, Zhang T, Liu Y (2006) Anaerobic treatment of phenol in wastewater under thermophilic condition. Water Res 40(3):427-434

Fikret KF, Pamukoglu MY (2003) Aerobic biological treatment of pretreated leachate by fed-batch operation. Department of Environmental Engineering. Enzym Microb Technol 33:588-595

Gasten DJ, Rozich AF (1986) Analysis of batch nitrification using substrate inhibition kinetics. Biotech Bioeng 28(3):461-465 
Gee CS, Makram T, John T (1990) Modelling under substrate inhibition conditions. Environ Eng 116:18-31

Gulsen H, Turan M (2002) Anaerobic akiskan yatakh reaktfirde kati atik depolama alani sizmti sulannm antilabilirligI, vol 8. Endustriyel Kirlenme Kontrolu Sempozyumu, Istanbul (in Turkish)

Hies P, Mavinic DS (2001) The effect of decreased ambient temperature on the biological nitrification and denitrification of a high ammonia landfill leachate. Water Res 35(8):2065-2072

Hollopeter JA, Dague RR (1995) Anaerobic sequencing batch reactor treatment of landfill leachate. WEF conference 19-95

Im JH, Woo HJ, Choi MW, Han KB, Kim CW (2001) Simultaneous organic and nitrogen removal from municipal landfill leachate using an anaerobic-aerobic system. Water Res 35(10):2403-2410

Inanc B, Calh B, Saatci A (2000) Characterisation and anaerobic treatment of the sanitary landfill leachate in Istanbul. Water Sci Tech 41(3):223-230

Jokela J, Kettunen RH, Sormunen KM, Rintala JA (2002) Biological nitrogen removal from municipal landfill leachate. Low-cost nitrification in biofilters and laboratory scale in situ denitrification. Water Res 36(16):4079-4087

Kennedy KJ, Lentz EM (2000) Treatment of landfill leachate using sequencing batch and continuous flow up-flow anaerobic sludge blanket (UASB) reactors. Water Res 34(14):3640-3656

Kettunen RH, Hoilijoki TH, Rintala JA (1996) Anaerobic and sequential anaerobic-aerobic treatments of municipal landfill leachate at low temperatures. Bioresour Technol 58:31-40

Kurniawan TA, Lo W, Chan G, Sillanpää ME (2010) Biological processes for treatment of landfill leachate. Dept. of Applied Biology and Chemical Technology and Lo Ka Chung Centre for Natural Anticancer Drug Development, The Hong Kong Polytechnic University, Hong Kong, PR China

Lin SH, Chang CC (2000) Treatment of landfill leachate by combined electro-fenton oxidation and sequencing batch reactor method. Water Resour 34(17):4243-4249

Lin CY, Chang FY, Chang CH (2000) Co-digestion of leachate with septage using a UASB reactor. Bioresour Technol 73:175-178

Madera C, Viviana VZ (2009) Landfill leachate treatment: one of the bigger and underestimated problems of the urban water management in developing countries. University of Valle, Calle 13 \# 100-00, Edif. 343, Cali, COL, 9th World Wide Workshop for Young Environmental Scientists WWW-YES-Brazil-2009: Urban waters: resource or risks? 26-30 October 2009

Maehlum T (1995) Treatment of landfill leachate in on-site lagoons and constructed wetlands. Water Sci Tech 32:129-135

Marttinen SK, Kettunen RH, Sormunen KM, Soimasuo RM, Rintala JA (2002) Screening of physical-chemical methods for removal of organic material, nitrogen and toxicity from low strength landfill leachates. Chemosphere 46(6):851-858

Park S, Choi KS, Joe KS, Kim WH, Kim HS (2001) Variations of landfill leachate's properties in conjunction with the treatment process. Environ Technol 22:639-645

Ramakrishnan A, Gupta SK (2008) Effect of hydraulic retention time on the biodegradation of complex phenolic mixture from simulated coal wastewater in hybrid UASB reactors. J Hazard Mater 153:843-851

Sahrigi AF, Ghanem II, Chui PC, Tay JH (2002) Two-phase anaerobic system for recycling of kitchen food residue and biogas production. Appropriate environmental and solid waste management and technologies for developing countries, vol 1. Istanbul, Turkey, pp 535-540

Sun HW, Peng YZ, Shi XN, Wang SY, Zhang SJ, Yang Q, Chen Y (2009) Start-up and steady operation of two stage UASB-SBR new process for treatment of real landfill leachate of high strength ammonia-nitrogen, Key Laboratory of Beijing Water Quality Science and Water Environment Recovery Engineering, Beijing University of Technology, J Environ Sci (China) 1480-1485

Torkian A, Amin MM, Kermanshahi RK, Salehi MS (2004) Granulation in UASB system treating slaughterhouse wastewater. Sci Food Agric 53:175-184

Turk O, Mavinic DS (1999) Influence of process changes on maintaining nitrite build-up activated sludge system acclimated to free ammonia. Water Res 23(11):1383-1388

Wu L, Peng C, Zhang S, Peng Y (2009) Nitrogen removal via nitrite from municipal landfill leachate, Beijing University of Technology, China. J Environ Monit 21(11):2032-2047

Wu JJ, Wu CC, Ma HW, Chang CC (2003) Treatment of landfill leachate by ozone-based advanced oxidation processes. Department of Environmental Engineering and Science, Feng Chia University, Taiwan Graduate Institute of Environmental Engineering, National Taiwan University 